\title{
Contributions in the Fields of Pathology Beginning With Spleen Lymphoma: A Review
}

\author{
Wilson IB Onuigbo* \\ Department of Pathology, Medical Foundation \& Clinic, Nigeria
}

Received: 踾: December 20, 2018; Published: 制: January 04, 2019

*Corresponding author: Wilson IB Onuigbo, Department of Pathology, Medical Foundation \& Clinic, Nigeria

\begin{abstract}
The study of the spleen may result from some happenstance. Also, it may be of some substance. Therefore, the aim of this study is to present personal contributions concerning both of these spleen pathologies. They are deemed to be worthy of documentation sequentially in terms of lymphoma, forensic pathology, melanoma metastases and even prospects of the target therapy of cancer.
\end{abstract}

Keywords: Spleen; Happenstance; Substance; Lymphoma; Forensic; Tuberculosis; Trauma; Splenomegaly; Hypotheses; Necrosis; Natural Factor; Cancer Cure

\section{Introduction}

The study of the spleen may reflect mere happenstance. Thus, concerning a paper written in Nepal [1] it contributed the chance finding of spleen injuries which complicated rib fractures. In contrast, the present study consists largely of a purposive evaluation of some diseases affecting the spleen. They are deemed to be worthy of documentation and may be presented as follows:

\section{Lymphoma}

Elsewhere [2] the author dwelt on 4 cases of lymphoma which occurred among his own indigenous group, the Ibos of Nigeria [3]. The major findings were that all were males aged between 11 and 50 years (mean 29 years). Here, global views are deemed to be worthy of documentation. Literature searches revealed findings in countries as alphabetically disparate as Brazil, Canada, China, Germany, Greece, India, Italy, UK and USA [4-17]. In sum, there is a general agreement as to lymphoma being a rare disease; its literature has dealt largely with diagnosis, prognostic factors, treatment indications and therapeutic options. In contrasting the Nigerian age of between 11 and 50 years (mean 29 years), the Chinese was aged 68 years [6], the Indian 43 years [10], and another was generalized as "elderly" [12], while the US patient was aged 75 years [17]. As for sex, all my patients were males. In contrast, the females featured in India [10,12] and USA [17]. Interestingly, the Chinese patient presented with associated acute pancreatitis [6]. Moreover, splenic rupture was present in the Indian [11]. Indeed, it has been generalized in Italy that "splenomegaly presents as an epiphenomenon of hepatic or systemic diseases" [13]. According to German workers [18], "Sonographic examination showed spleen involvement in 43 patients with histological evidence of malignant lymphoma". From the UK [15], "both routine and more recently developed techniques, including functional imaging" were reviewed. From that country also [14], we gathered that "Inflammatory and reactive processes in the spleen can also provide clinical, radiological or pathological mimicry of lymphomatous involvement." Incidentally, I am persuaded that the local cases were classical enough for personal diagnosis.

\section{Death Following Traumatization of Tuberculous Spleen}

A recent paper asked whether there was progress in the autopsy diagnosis of sudden death in adults and answered positively with the role of the Police surgeon [19]. Therefore, this paper concerns the author's such role in a case of family brawl that ended in a woman's death. Happiness was the name of the girl who identified the body of her mother to me. There was the history of sudden death following a family brawl. On opening the abdomen, there was hemoperitoneum. The source was the enlarged ruptured spleen. Microscopy revealed the interesting mitigating presence of tuberculosis. In other words, manslaughter was the fitting exposition. Splenic tuberculosis was a surprise lesion in this setting. Incidentally, the name of the witness in the local case was Happiness. Interestingly, among the Ibo or Igbo Ethnic Group, whose domain is in the South Eastern Region of Nigeria, there is an important "Naming Ceremony."

In particular, "The ceremony is observed with feasting and general rejoicing." In fact, it is necessary to add that "circumstances, or prevailing conditions of the time, may suggest an appropriate 
name whereby the unusual happenings are kept in remembrance [3]." I am persuaded that the cog in the wheel of happy matrimony in this pitiful case was the underlying tuberculosis together with splenomegaly. In effect, it possibly constituted the cause of disagreement in the household, thereby bringing doom instead of gloom expected in the marriage. On the positive side, the experience of Barbados authors was to the effect that forensic autopsy can assist in monitoring patient care (and) "can be a vehicle for continuing education" [20]. Incidentally, spleen friability also reared its ugly head as I reported elsewhere with regard to sports medicine [21].

\section{Tropical Splenomegaly as a Forensic Challenge}

A 78-year-old woman died and her body was not buried for a month. This was in order that forensic autopsy might clear the air regarding the suspicion of foul play among the family members. In their underdevelopment locality, an enlarged spleen while the patient was alive was held to be a "devilish tortoise" translated locally as "mbekwu afo," i.e., "belly tortoise"! Indeed, only the stature of the author guaranteed the family's acceptance of any such non-devilish explanation! At autopsy, the author confirmed natural death due to tropical splenomegaly and informed all and sundry to that effect [22].

\section{Spleen Metastases in Melanoma}

In a series of 18 papers published as a book on metastatic melanoma [23], one article was devoted to its involvement of the spleen [24]. That article contained a striking example from old Beadle's work of 1894 [25]. It ran as follows: "Greatly enlarged, weighed $1 \mathrm{Ib}$., firm, and dark in color. Two deposits the size of large peas and of a pale color were situated in the interior of the organ." Clearly, in modern times, the ultimate impression is that of the scarcity of melanotic colonies. Thus, the picture remains that of single case reports found in the literature as regards primary organs like the bowel , ovary, kidney and lung [26-29]. Incidentally, from Rio de Janeiro [30], a team considered that "The spleen is the main mass of lymphoid tissue in the body, but it was not a typical site of neoplastic metastasis.

\section{The Origins of My Cancer Studies}

As Providence had it, I left the young University College, Ibadan, in Nigeria, in 1953, to complete the clinical training at the famous Glasgow Western Infirmary in Scotland. Incidentally, that pathology institution was the one described as being second to none in Britain [31]. On his part, the Head of Pathology, Professor Cappell, was described as a man of excellence [32]. In the memory of his own master, he himself had set in place the Muir Medal Examination. Although I did not get it, he praised my script on the question based on the epidemiology of lung cancer. Moreover, he pointed to the impressive rows of the old Record Books as being available for research. Furthermore, the British Medical Journal had been offered at reduced price for students. Thus, I began to purchase it. Soon, it occurred to me that 100 cases were often being written up. So, I combed that number of lung cancers and appreciated and trend, namely, a startling of not aortic haphazard disarray but a lymphvessel one-sided colonization of the adrenal gland.
In sum, 1000 cases were obtained. The script was submitted on April 4, 1957, to the British Journal of Cancer, which published it in June [33], the month of my graduation. In particular, Prof Cappell did me the honor of publishing the findings in his Revision of the famous Muir's Text Book of Pathology the following year thus [34] Onuigbo, working in my Department, has shown that spread to the adrenals is predominantly to the ipselateral side and this distribution indicates the lymphatics rather than the arterial blood stream as the usual route of metastases. The next step was to undergo postgraduate training in the Department itself while on study leave from the Ministry of Health of the Eastern Region of Nigeria. Soon, it occurred to me not to display the cut parts on the table but to retain them mostly as an axial block from the cricoid cartilage to the aortic bifurcation [35]. This method made it possible to study the $45 \mathrm{~cm}$ long thoracic duct as one whole, instead of the then prevailing problem of examination after multiple cross sections [36]. In particular, serendipity crept in and it became possible to study this duct on a single microscope slide with the Swiss-roll method [37]. Thereby, I noted, the ultimate fate of the cancer cells being transported during the moment of death as follows: "Necrosis of the cancer cells was apparent in 3 cases, but it was clear that this had occurred in association with large aggregates of the malignant cells and that among each aggregated cells red blood corpuscles abounded."

\section{Necrosis of Cancer Cells}

This element of necrosis became the king pin of my research. How? First, Nature has provided the two sub-sets necessary in research, namely, lively individual cancer cells and also clumped dying cancer cells [38]. What remains are manifold. Most importantly, there are the consenting patients [39]. Next, the ordinary cannulation is employed [40]. In particular, there is now the new technique of intravital video-microscopy [41]. Certainly, in translational laboratories, which have sprung up since the declaration of the war on cancer and are well funded $[42,43]$, the aim should be to view the duct and to retrieve the above named two-fold natural materials. I have taken the trouble to identify the responsible intrinsic factor and to name it as the "Erythrocyte Associated Necrosis Factor", i.e., EANF [44]. It is argued that this Factor operates differently from the suspected roles of both anoikis and stem cells [45].

\section{The Visionary Views of Medical Masters of Yester Years}

We may go first to William Harvey [46], who wrote a letter on 28th April, 1652, and included the following: Nature is nowhere accustomed more openly to display her secret mysteries than in cases where she shows traces of her workings apart from the beaten track; nor is there any better way to advance the proper practice of medicine than to give our minds to the discovery of the usual law of nature, by the careful investigation of these rarer forms of disease. William Gull in his 1870 Harveian Oration also addressed his listeners on Nature! As he aput it instructively [47], "what the student of nature's mysteries always needs to remember is that his position is viewing things from his own centre rather than from the centre. What he has chiefly to avoid is that discouragement does not pass into denial." 
In another Harveian Oration [48], Sir William Roberts ruminated on the theme that "Science advances by a succession of discoveries." As he continued, "Each discovery constitutes a permanent addition to natural knowledge-and furnishes a post of vantage for, and a suggestion to, further discoveries." On his part, Julius Cohnheim [49], the great German pathologist, was forthright that autopsy findings "are all in a manner experiments instituted by nature, which we need only rightly interpret to get a clear idea of the causes, laws of growth, and significance of the tumour." Indeed, what I clearly identified of late are consistent with Nature's footsteps, which are identifiable as EANF in our own age.

\section{EANF Explains Riddles of Different Sorts}

Regression: I reviewed the notions concerning it with respect to breast cancer during the 1753 to 1897 period [50]. Among the reigning theories was Praying. An engaging example was that of a monk due to be amputated for bone cancer [51]. Lo and behold! He prayed throughout the night with pristine profundity and inestimable intensity. Daylight beamed on his lively limb! Therefore, it is hypothesized that, when EANF is produced tremendously, its effect must be crucially maximal as a regression [52].

Fewness of Renal Metastases: The kidneys take a quarter of the stroke volume of the blood [53]. The anatomy further ensures close admixture of red cells and cancer cells in the glomeruli. It is argued, therefore, that the close admixture of red cells and EANF matters whether in the thoracic duct or in the glomerulus. In the latter, this close interaction is responsible for the infrequency or renal metastases [54].

Metastasizing Lung Cancer Cells Manifest Ubiquity in the Blood Stream: Millions of lung cancer cells are released into the blood stream [55]. Surely, these cells reach the lymph nodes readily. The paucity of nodal colonization, including centrifugal disposition requires research [56,57], especially with reference to the isolated popliteal nodes [58], the emphasis being on the role of EANF.

Explanation of Scarcity of Spleen Metastases: The grand anatomical eminence of the spleen rests among other things on the manufacture of red cells [59]. Clearly, lung cancer cells and red cells must comingle in the spleen. Such comingling has been shown to lead to cancer necrosis. It is inferred therefore, that EANF should be recognized as part and parcel of the oddity of the scarcity of spleen metastases.

\section{Conclusion}

In an as yet unpublished finding regarding "bulky" lung cancers regarded as those over $10 \mathrm{~cm}$ across [60], none extended beyond the thorax surprisingly. I am persuaded that this is because of the enormity of the secreted EANF. Meanwhile, let me urge that necrotizing of cancer cells should be pursued. Thereafter, drug designing and development should be facilitated [61]. In this context, there was a time when bleeding was a killer and the discovery of Vit K [62]. Yes! May the identification of EANF hold such a promise sooner than later.

\section{References}

1. Subedi N, Yadav BN, Shivendra Jha (2014) Liver and spleen injuries and associated rib fractures: An autopsy study. J Forensic Res 5(5): 1000240.

2. Onuigbo WIB (2018) Lymphoma of the spleen in a developing community. J Immunol Inflammat Dis Ther 1-10003: 1-2.

3. Basden GT (1966) Niger Ibos. Lond, Cass, USA.

4. Dos Santos TS, Tavares RS, De Farias DLC (2017) Splenic marginal zone lymphoma: A literature review of diagnostic and therapeutic challenges. Rev Bras Hematol Hemoter 39(2): 146-154.

5. Brox A, Shustik C (1993) Non-Hodgkin lymphoma of the spleen. Leuk Lymph 11(3-4): 165-171.

6. Wu CM, Cheng LC, Lo GH et al. (2007) Malignant lymphoma of spleen presenting as acute pancreatitis: A case report. World J Gastroenterol 13(27): 3773-3775.

7. Li M, Zhang $\mathrm{L}, \mathrm{Wu} \mathrm{N}$, et al. Imaging findings of primary splenic lymphoma: A review of 17 cases in which diagnosis was made at splenectomy. PLos one 8(11): 680264.

8. Falk S, Stutte HJ (1990) Primary malignant lymphomas of the spleen: A morphologic and immunohistochemical analysis of 17 cases. Cancer 66(12): 2612-2619.

9. Kalpadakis C, Pangalis GA, Angelopoulou MK, et al. (2013) Treatment of splenic marginal zone lymphoma with rituximab monotherapy: Progress report and comparison with splenectomy. Oncologist 18(2): 190-197.

10. Sarma YS, Sriharibabu M, Nayak SR, Spoorthy K (2016) A rare case of primary follicular lymphoma of the spleen. J NTR Univ Health Sci 5(1): $59-62$.

11. Ingle SB, Hinge CR (2016) Primary splenic lymphoma: Current diagnostic trends. World J Clin Cases 4(12): 385-389.

12. Kattepur AK, Rohith S, Shivaswamy BS, et al. (2013) Primary splenic lymphoma: A case report. Indian J Surg Oncol 4(3): 283-290.

13. Iannitto E, Tripodo C (2011) How I diagnose and treat splenic lymphomas. Blood 117(9): 2585-2595.

14. Wilkins BS (2010) Lymphomas involving the spleen. Diag Histopathol 16(3): 116-124.

15. Bhatia K, Sahdev A, Rodney HR (2007) Lymphoma of the spleen. Seminars in Ultrasound, CT and MRI. 28(1): 12-20.

16. Howard MT, Dufresne S, Swerdlow SH, Cook JR (2009) Follicular lymphoma of the spleen multiparameter analysis of 16 cases. Am J Clin Pathol 131(5): 656-662.

17. Abraksia S, Kumar PD, Kasal J (2000) Two unusual lymphomas. J Clin Oncol 18(21): 3731-3733.

18. Gorge C, Schwerk WB, Gorge K, Havemann K (1990) Sonographic patterns of the affected spleen in malignant lymphoma. J Clin Ultra 18(7): 569-574.

19. Onuigbo WIB (2018) Mild trauma on an enlarged tuberculous spleen probably caused sudden death in a previously happy marriage. Journal of Forensic Sciences \& Crime 1(9): 1-3.

20. Prussia PR, Martin P (1987) Autopsy experience in Barbados. WI Med J 36(1): 2-7.

21. Onuigbo WIB (2016) The variegated lesions found at autopsy in sudden death in a developing community. Forensic Pathol 1(2): 104.

22. Onuigbo WIB (2018) Tropical splenomegaly syndrome as a forensic challenge. J Forensic Sci Crim Investig 8(4): FSCI.MS.ID.555744.

23. Onuigbo WIB (2018) History of Metastatic Melanoma, Latvia: LAP LAMBERT Academic Publishing 
24. Onuigbo WIB (2016) Spleen secondaries as melanoma masses: Historical highlights. An Physiol Curr Res 6(6): 1000244.

25. Beadles CF (1894) A case of multiple malignant growths. Trans Path Soc Lond 45: 188-197.

26. Okuyama T, Oya M, Ishikawa H (2001) Isolated splenic metastasis of sigmoid colon cancer: A case report. Jap J Clin Oncol 31: 341-345.

27. Ghani AA, Hashmi ZA, Chase DM (2010) Intraparenchymal metastases to the spleen from ovarian cancer: a case report. J Med Case Rep 4: 30.

28. Moir JAG, Sen G, Saif R (2011) Isolated splenic metastasis from renal cell carcinoma: case report and review. Case Rep Gastroenterol 5(1): 166171.

29. Cai Q Kragel P (2015) Isolated splenic metastasis in a patient with lung carcinoma: Case report and review of the literature. J Clin Exp Pathol $5: 252$.

30. Rosa N, Martins S, Lamelas J (2012) Isolated splenic metastasis of colon cancer: a case report and literature review. J Coloproctol (Rio J) 32(1): 89-94.

31. Jacyna LS (1988) The laboratory and the clinic: The impact of pathology on surgical diagnosis in the Glasgow Western Infirmary, 1875-1910. Bull Hist Med 62(3): 384-406.

32. Anonymous (1977) Obituary notice of Daniel Fowler Cappell. Journal of Pathology 122(3): 175-183.

33. Onuigbo WIB (1957) Some observations on the spread of lung cancer in the body. Br J Cancer 11(2): 175-180.

34. Cappell DF (1958) Muir's Text-Book of Pathology. ( $7^{\text {th }}$ edn). Lond, Edward Arnold (Publishers) Ltd, New York, USA, pp. 505.

35. Onuigbo WIB (1967) The carriage of cancer cells by the thoracic duct. Br J Cancer 21(3): 496-500.

36. Udah H (1960) Pathological study of ductus thoracicus with special reference to leukemia. Acta Hematol Jap 23: 723-739.

37. Onuigbo WIB (2017) Hypothesis on the swiss-roll method of investigating cancer necrosis during metastasis in the human thoracic duct. J Trans Res 1(1).

38. Onuigbo WIB (2016) Hypothesis: Nature has provided the two subsets required for translational lung cancer research. Int J Cell Sci Mol Biol $1(1)$.

39. Onuigbo WIB (2014) Historical origins of informed consent in cancer surgery. J Forensic Res 5: 246-247.

40. Mittleider D, Dykes TA, Cicuto KP (2008) Retrograde cannulation of the thoracic duct and embolization of the cisterna chyli in treatment of chylous ascites. J Vasc Intervent Radiol 19(2): 285-290.

41. Chambers AF, Mac Donalt IC, Schmidt EE, Koop S, Morris VL, et al. (1995) Steps in tumor metastasis: new concepts from intravital videomicroscopy. Cancer Metastasis Rev 14(4): 279-302.

42. Sporn MB (1996) The war on cancer. Lancet 347(9012): 1377-1381.

43. Woolf SH (2008) The meaning of translational research and why it matters. J Am Med Assoc 299(2): 211-213.
44. Onuigbo WIB (2013) Nature's necrosis factor when associated with erythrocytes may not only explain the surprises in lung cancer metastases but also suggest target therapy. Med Hypotheses 80(6): 698700 .

45. Sakuma Y, Tateuchi T, Nakamura Y, Yoshihara M, Matsukuma S, et al. (2010) Lung adenocarcinoma cells floating in lymphatic vessels resist anoikis by expressing phosphorglated Src. J Pathol 220(5): 574-85.

46. Willis R (1847) Translation from Latin of The works of William Harvey. Lond: Sydenham Society pp. 153, 186, 616.

47. Gull W (1870) The Harveian Oration. Lond, Churchill, UK, p. 12.

48. Roberts W (1897) The Harveian Oration. Lond, Smith, Elder \& Co. p. 20.

49. Cohnheim J (1889) Lectures on general pathology. Section 1. London. The New Sydenham Society, p.14.

50. Onuigbo WIB (2012) Spontaneous regression of breast carcinoma: review of English publications from 1753 to 1897. Oncol Rev 6(2): 171174.

51. Pack GT (1967) Saint Peregrine, OSM The patron saint of cancer patients. CA Cancer J Clin 17(4): 181-182.

52. Onuigbo WIB (2016) Nature's intrinsic “Erythrocyte Associated Necrosis Factor" (EANF) can explain cancer regression. Res Chron Health Sci 2(2): 266-268.

53. Wright S (1952) Applied physiology, ( $9^{\text {th }}$ edn.). Oxford University Press, London, UK.

54. Onuigbo WIB (2017) The relative fewness of renal metastases in lung cancer is probably explicable with the "Erythrocyte Associated Necrosis Factor" which may be an Oncobiomarker. J Oncobiomark 3(1): 3.

55. Onuigbo WIB (2015) Can immunopathology explain why metastasizing lung cancer cells manifest ubiquity in the blood stream but selectivity in lymph node colonization? Immunochem Immunopathol 1:2.

56. Onuigbo WIB (1961) Centrifugal metastasis in lung cancer. British Journal of Diseases of the Chest 55: 86-90.

57. Onuigbo WIB (2014) Is there a natural translational system suitable for the target therapy of lung cancer? Trans Med 4: 2 .

58. Onuigbo WIB (2010) The popliteal lymph node group as a naturally positioned model for research on lung cancer metastasis. J Cancer Res Experiment Oncol 2(3): 27-28.

59. Onuigbo WIB (2016) Does the "Erythrocyte Associated Necrosis Factor" explain the scarcity of metastases in the spleen? Trans Med 6(3): 177.

60. Onuigbo WIB. The spread of "bulky" lung cancers. In Press.

61. Onuigbo WIB (2017) Necrotizing of cancer cells is possible through drug designing and development. Novel Approach Drug Design Dev 1(4): NAPDD.MS.ID.555566.

62. Laurence DR, Bennette PN (1987) Clinical Pharmacology (6 $6^{\text {th }}$ edn), ELBS: Churchill: Livingstone, p. 567-570. 
ISSN: 2574-1241

DOI: 10.26717/BJSTR.2019.12.002308

Wilson IB Onuigbo. Biomed J Sci \& Tech Res

(c) (P) This work is licensed under Creative

Commons Attribution 4.0 License

Submission Link: https://biomedres.us/submit-manuscript.php

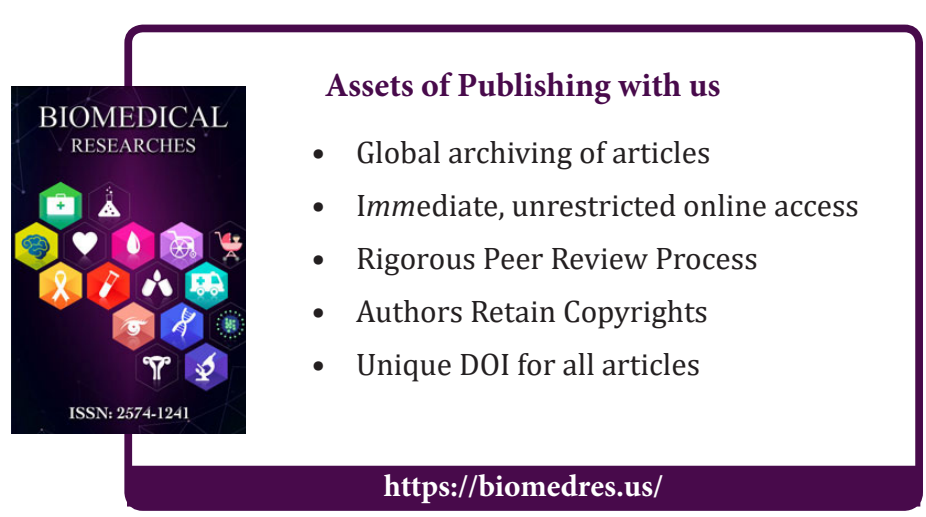

